\title{
The Mystique of Hepatic Tolerogenicity
}

\author{
THOMAS E. STARZL, M.D., Ph.D., NORIKO MURASE, M.D., \\ ANTHONY DEMETRIS, M.D., MASSIMO TRUCCO, M.D., \\ and JOHN FUNG, M.D., Ph.D.
}

\begin{abstract}
The evolution of clinical transplantation has hinged on 2 seminal turning points. The first was the demonstration in 1953 by Billingham, Brent, and Medawar that chimerism-associated tolerance could be induced deliberately in neonatal mice by infusing adult donor hematolymphopoietic cells. This discovery escalated in a straight line over the next 15 years to successful bone marrow transplantation in humans. The second turning point was the demonstration that organ allografts could self-induce tolerance under an umbrella of immunosuppression, or in some species without immunosuppression. Unfortunately, it was incorrectly concluded by most immunologists and surgeons that bone marrow and organ engraftment involved different immune mechanisms. In a derivative error, it became widely believed that the tolerogenicity of the liver differed fundamentally not only from that of bone marrow but also from that of other whole organs.

These errors became dogma and were not corrected until low level donor leukocyte chimerism was found in humans and animals bearing long surviving liver, kidney, heart, and other kinds of allografts. With successful bone marrow transplantation, the trace population consisted of recipient rather than donor leukocytes. Thus, the consequences of organ and bone marrow engraftment were mirror images. From these observations, it was proposed that the engraftment of all kinds of organs as well as bone marrow cells $(B M C)$ involved host versus graft (HVG) and graft versus host $(G V H)$ reactions with reciprocal induction of variable degrees of specific non-reactivity (tolerance). The maintenance of the tolerance was an active and ongoing process requiring the persistence of the transplanted fragment of the donor immune system. The immune responsiveness and unresponsiveness to both organ and bone marrow allografts are thought to be governed by the migration and localization of leukocytes. The clarifying principles of transplantation immunology that have emerged from the chimerism studies are relevant to the adaptive immune response to microbial, tumor, allogeneic, and self antigens. These principles should be used to guide efforts to systematically induce tolerance to human tissues and organs, and perhaps ultimately to xenografts.
\end{abstract}

KEY WORDS: immunologic tolerance, organ allograft, liver allograft, liver tolerogenicity, liver transplantation, clonal exhaustion-deletion, immune indifference

\footnotetext{
Objectives

Upon completion of this article, the reader should be able to understand 1) the meaning and mechanisms of acquired tolerance;2) the adaptive immune response to microorganisms vis a vis the response to organ and bone marrow allografts; and 3) the reasons for the liver's unusual tolerogenicity relative to that of other organs.

Accreditation

The Indiana University School of Medicine is accredited by the Accreditation Council for Continuing Medical Education to provide continuing medical education for physicians.

Credit

The Indiana University School of Medicine designates this educational activity for a maximum of 1.0 hours credit toward the AMA Physicians Recognition Award in category one. Each physician should claim only those hours of credit that he/she actually spent in the educational activity.

Disclosure

Statements have been obtained regarding the authors' relationships with financial supporters of this activity. There is no apparent conflict of interest related to the context of participation of the authors of this article.
}

Thomas E. Starzl Transplantation Institute, Departments of Surgery, Pathology, and Pediatrics, University of Pittsburgh Medical Center, Pittsburgh, Pennsylvania.

Reprint requests: Dr. Thomas E. Starzl, 3601 Fifth Avenue, Falk Clinic, Pittsburgh, PA 15213.

Copyright $\odot 2000$ by Thieme Medical Publishers, Inc., 333 Seventh Avenue, New York, NY 10001, USA. Tel.: +1(212) 584-4662. 0272-8087,p;2000,20,04,497,510,ftx,en;sld00074x 
The emergence of transplantation has seen the development of increasingly potent immunosuppressive agents, better methods of tissue and organ preservation, refinements in histocompatibility matching, and numerous innovations in surgical technique. 1,2 Although these advances helped to make organ transplantation a practical and valuable clinical service, the feasibility of such procedures ultimately depended upon a natural quality of all organs, namely their ability to induce variable degrees of donor specific nonreactivity (i.e., tolerance). ${ }^{3}$

In humans, allogeneic tolerance is a normal immunologic option that generally requires a protective umbrella of immunosuppression. However, spontaneous tolerance to organs, most commonly the liver, has been recorded in pigs, rats, and mice. In addition to its greater tolerogenicity relative to other organs, the liver is more resistant to antibody mediated hyperacute rejection. ${ }^{4}$ Such observations, suggesting that the liver is an "immune privileged" organ led to a controversy of more than 25 years duration. The issue was whether tolerogenicity is a unique property of the liver, or a quality possessed by all organs, varying only in degree.

\section{ORGAN TOLEROGENICITY: THE ORIGIN OF THE CONCEPT}

\section{A Pathfinder Kidney Experience}

In retrospect, the inherent tolerogenicity of organs was evident from the beginning, although passionately denied. Between January 1959, and January 1963, there were 6 examples of survival of greater than one year after kidney transplantation to human recipients preconditioned with total body irradiation (TBI): one in Boston $^{5,6}$ and 5 divided between two.Paris centers. ${ }^{7,8}$ Under today's regulatory restrictions, these trials probably would have been blocked at an institutional review board (IRB) level. The longest survival with TBI preconditioning in an animal model had been only for 73 days, following kidney transplantation between beagle dogs. ${ }^{9}$ Furthermore, the first successful clinical case in Boston, in which the donor was a fraternal twin, provided the only long survival in a dozen attempts at that institution. In France the 5 long survivals also were exceptions to the usual outcome of recipient death.

In addition to these 6 cases, a non-irradiated human kidney recipient in Boston had been treated with azathioprine from the time of transplantation on April 5, 1962. ${ }^{10}$ Although this seventh long-surviving renal allograft (from an unrelated donor) was failing by January, 1963, it provided enough function to keep the patient dialysis-free for another 8 months. ${ }^{1}$ Unlike the TBI trials, a track record had been established in animals. Survival longer than 100 days had been documented by
Calne $^{12}$ (with Murray ${ }^{13}$ ) in about $5 \%$ of mongrel canine kidney recipients treated with 6-mercaptopurine or its imidizole derivative, azathioprine.

The limited efficacy of azathioprine, alone or in combination with other cytotoxic drugs, was found to be the same in humans ${ }^{10}$ as in the preceding dog studies. In contrast, 8 of the first 10 human kidney recipients treated with the combination of azathioprine and prednisone at the University of Colorado had prolonged survival. These cases, compiled between October 1962, and March 1963, ${ }^{3}$ constituted the first successful series of human organ transplantation and included 2 patients who still bear the longest continuously functioning kidney allografts in the world (> 37 years).

\section{Renal Tolerogenicity}

From a practical point of view, the significance of the Colorado series was the high rate of patient and graft survival. Its far more important conceptual implications were capsulized in the title of the report published in October 1963: "The reversal of rejection in human renal homografts with subsequent development of homograft tolerance." 3 Although the findings could not be explained, they provided the bedrock upon which the organ-defined specialties of clinical transplantation could be developed, using immunosuppressive drugs in combination that were ineffective when administered alone.

The reversal of rejection in the human kidney recipients was readily monitored by renal function tests after instituting large doses of prednisone $(200 \mathrm{mg} /$ day) to baseline immunosuppression with azathioprine. The evidence was equally clear that the renal allografts had self-induced partial tolerance under the cover of immunosuppression. After passing through rejection crises, most of the patients had a progressively diminishing need for immunosuppression, usually to doses lower than those which initially failed to prevent rejection. The tolerance was complete enough to allow many of the kidney recipients to be released to an unrestricted environment without the lethal immunologic invalidism that had been widely predicted. More than a third of a century later, remarkably similar observations leading to what was called "prope tolerance" were reported by Calne et al. ${ }^{14,15}$ in patients treated with a combination of modern day immunosuppressants. In fact, 2 of the 10 recipients in the 1963 report have been free of immunosuppression for 34 and 6 years, respectively. 16

Successful transplantation of the liver, ${ }^{17,18}$ and eventually all of the other extrarenal organs depended on the same phenomena as with kidney transplantation: the reversal of rejection and the evolution of specific non-reactivity. In 1966, adjunct antilymphocyte globulin [ALG] was added to azathioprine and prednisone ${ }^{19}$ 
TABLE 1. Empirical Therapeutic Dogma of Immunosuppression

\begin{tabular}{|c|c|}
\hline Ingredients of Strategy & Baseline Agents \\
\hline 1. Baseline therapy & 1. Azathioprine* \\
\hline $\begin{array}{l}\text { 2. Secondary adjustments of prednisone } \\
\text { dose, or antilymphoid agents** }\end{array}$ & 2. Cyclosporine \\
\hline $\begin{array}{l}\text { 3. Case to case trial (and potential error) } \\
\text { of weaning. }\end{array}$ & 3. Tacrolimus \\
\hline
\end{tabular}

*Alone or with prophylactic prednisone. Equivalent results were obtained with cyclophosphamide instead of azathioprine.

**:Initially used for prophylactic "induction."

in the first "triple drug cocktail," and as more efficient baseline drugs (e.g., cyclosporine and tacrolimus) and adjunct agents (e.g., monoclonal antilymphoid antibodies) became available they were readily substituted for the previous best immunosuppressants. However, the basic strategy was always the same (Table 1).

\section{Hepatic Tolerogenicity}

Until 1965, the only published clue that the liver might be unusually tolerogenic was the observation in untreated mongrel canine recipients that the intestine and pancreas had very little histopathologic evidence of rejection if they were components of multivisceral allografts that also included the liver. ${ }^{20}$ The finding was confirmed 30 years later in a rat version of the same multivisceral procedure. ${ }^{21,22}$ However, the first unambiguous evidence of hepatic tolerogenicity was the demonstration in 1964 that mongrel dogs bearing orthotopic liver allografts under azathioprine therapy frequently could have their immunosuppression stopped after 4 months with long subsequent survival; 235 years later most of the drug free recipients remained well. ${ }^{24}$

The significance of this observation in canine liver recipients was extensively discussed ${ }^{23}$ : "Although the early recovery after liver homotransplantation has many hazards ... the frequency and rapidity with which dogs could be withdrawn from immunosuppression without an ensuing fatal rejection is remarkable. ... The consistency of this state of host-graft nonreactivity and the rapidity with which it seemed to develop exceeds that reported after canine renal homotransplantation. The explanation for this is not apparent, but conceivably, the large antigenic mass could play a role or, alternatively, perhaps the liver with its enormous regenerative capacity is simply capable of sustained function in the face of continuing but minimal chronic rejection. [However,] findings in the serial biopsies obtained after discontinuance of therapy do not support the latter hypothesis ..."

Soon thereafter in France2s and then elsewhere, ${ }^{26-29}$ spontaneous liver engraftment in untreated outbred pigs was reported in $1 / 3$ to $1 / 4$ of hepatic replacement experiments. Many of these porcine recipients first passed through one or more self-resolving rejection crises. $28.30^{\circ} 31$ In the 1970 s, the phenomenon of tolerance induced by the liver was demonstrated in untreated rats (see later discussion).

\section{AN EPISTEMOLOGIC COLLAPSE}

The discovery that variable donor specific nonreactivity could be induced by organ allografts under an umbrella of non-specific drug immunosuppression was the second principal turning point from which clinical transplantation evolved. ${ }^{1,2}$ The first had been the demonstration by Billingham, Brent and Medawar in 1953 that transplantation tolerance could be induced in neonatal mice by infusing these immunologically immature (i.e., defenseless) recipients with allogeneic hematolymphopoietic cells from a histocompatible or $F_{1}$ hybrid adult donor. ${ }^{32,33}$ If the recipients survived to adult life, ostensibly with a "replaced" hematolymphopoietic (i.e., immune) system, skin grafts from the same donor strain (but not from third party donors) were permanently accepted.

The next step was to simulate in adult mice the immunologically defenseless state of the neonatal animals by TBI, followed by the infusion of donor bone marrow cells (BMC). When these experiments were successful, 34 the stage was set for clinical bone marrow transplantation. However, this application was delayed for a decade until hụman leukocyte antigen (HLA) matching became available. ${ }^{35-38}$ As in the experimental models, graft versus host disease (GVHD) was a lethal consequence of the procedure in humans unless there was a good tissue match. Efforts to precondition canine kidney recipients with TBI and donor bone marrow infusion yielded only a single 73 day survivor. ${ }^{9}$ After this strategy failed in clinical trials, the use of TBI alone was rewarded by the long survival of a handful of human kidney recipients (see earlier section, "A Pathfinder Kidney Experience"). Not unreasonably, it was concluded that successful organ transplantation was based on fundamentally different principles than bone marrow transplantation.

The two turning points had now diverged in opposite directions, one leading to clinical bone marrow transplantation, and the other to organ transplantation. Moreover, a conceptual error had been introduced that distorted the orderly development of transplantation immunology, and of all other branches of immunology. The error was the conclusion "by consensus" that organ engraftment occurred by different mechanisms than the chimerism-dependent ones associated with neonatal tolerance and its clinical analogue of bone marrow transplantation. 


\section{The Liver-Specific Dogma}

The mistake subsequently was compounded by the argument that the mechanisms of hepatic tolerogenicity differed fundamentally, not only from those of bone marrow, but also from those leading to engraftment of other organs. This contention was based on the demonstration, first in spontaneously tolerant pigs and then in untreated rodent recipients of liver allografts ${ }^{40-42}$ that the tolerization self-induced by the liver extended to donor skin transplanted at the same time or later, and to other donor organs. Except for the presumed absence of donor leukocyte chimerism in the recipients, however, the acquired donor-specific non-reactivity was indistinguishable from that in the chimerism-associated neonatal tolerance of Billingham, Brent and Medawar, 32,33 and the experimental models of bone marrow transplantation ${ }^{34}$ that by this time had been brought to the clinic.

The spontaneous tolerance in pig liver recipients was unpredictable. However, it could be reliably reproduced in about $15 \%$ of congenic rat strain combinations. Consequently, rat models came to dominate research efforts to explain the phenomenon of spontaneous liver tolerance. ${ }^{43-47}$ The more recent demonstration that livers self-induce such tolerance in more than $80 \%$ of mouse strain combinations ${ }^{48}$ has generated a second windfall of mechanistic investigations. ${ }^{49-54}$ The mouse studies have been of particular interest because the principles of mammalian immunology have been derived so much from studies of this species.

In the ostensible absence of donor leukocyte chimerism, Davies, Kamada, and Rosen ${ }^{55}$ demonstrated specific deletion of cytotoxic antidonor lymphocytes from the thoracic duct, lymph nodes, and hepatic tissue of spontaneously tolerant rat liver recipients. The possibility implicit in these findings that the liver is a focus of peripheral tolerance induction has resurfaced with the studies by Crispe ${ }^{56}$ of interactions within the liver between thymus-dependent circulating $T$ cells and thymus-independent $\mathrm{T}$ cells with natural killer (NK) cell markers.

In addition, it was postulated that soluble major histocompatibility complex (MHC) Class I antigens secreted by the hepatocytes were responsible for the spontaneous hepatic tolerance. $39,40,55,57-59$ A subsequent but still liver-specific modification of this soluble antigen hypothesis ${ }^{60.61}$ accommodated the discovery in 1992 of donor leukocyte chimerism in human liver recipients (see later discussion). In the revision, Calne suggested that the soluble Class I antigen was a critical co-factor without which engraftment and persistence of donor leukocytes could not occur, while concluding that the persistence of late stage microchimerism was epiphenomenal. ${ }^{60}$

Studies in mice ${ }^{48}$ including those with "knockedout" MHC class I genes ${ }^{62}$ have not supported the liverspecific hypotheses. Importantly, it has been established that spontaneous tolerance also can be induced in mice by heart ${ }^{48,63}$ and kidney allografts, ${ }^{64}$ although in a much smaller number of donor-recipient strain combinations than with mouse liver allografts.

\section{The Colorado Hypothesis}

The exhaustion and deletion of an antigen specific clone had been postulated in the late 1950s to explain the acquisition in animals of tolerance to heterologous protein (with the aid of 6-mercaptopurine ${ }^{65}$ ), and to allogeneic splenocytes (without the need for immunosuppression $\left.{ }^{66}\right)$. The acceptance of clonal exhaustiondeletion as a "real phenomenon" by early workers was evidenced by extensive reviews in $1967^{67}$ and $1968^{68}$ by some of the most distinguished pioneers in immunology. Clonal exhaustion-deletion also was invoked at a very early time to explain the characteristic immunologic confrontation (rejection) and resolution (graft acceptance) that occurred with kidney engraftment. 69

Liver engraftment from the Colorado perspective was a form of donor specific tolerance that differed from kidney engraftment only quantitatively, exemplified by the ability of long-surviving canine ${ }^{23,24}$ and human liver recipients ${ }^{70-72}$ to stop all immunosuppression more frequently than kidney recipients (Fig. 1). As with the kidney allografts, the seminal mechanism of hepatic tolerogenicity was postulated to be clonal exhaustiondeletion ("clone stripping"). However, the ideas depicted in Figure 2 were not taken seriously. In addition to showing clonal exhaustion-deletion as the primary explanation of allograft acceptance, other features proposed in this first book on liver transplantation (published in 196973) were ahead of their time.

For example, alloantigen presentation leading to induction of the expanded clone was depicted via host macrophages (Fig. 2) rather than by the dendritic cells (DC) that would not be described by Steinman and Cohn ${ }^{74}$ until 1973. The discovery of apoptosis also lay ahead. Nevertheless, the immune competent cells proliferating in response to alloantigen were depicted in Figure 2 as selectively vulnerable, accounting for the emergence of donor-specific non-reactivity (tolerance) under treatment with immunologically non-specific immunosuppressants.

Despite the logic of clonal exhaustion-deletion, this mechanism of acquired tolerance abruptly disappeared from the literature. To our knowledge, clonal exhaustion-deletion was not mentioned a single time as an explanation for acquired tolerance in the voluminous immunology and transplantation literature spanning 1970-1990. The dismissive treatment could be explained in part by the theoretical status of clonal exhaustion-deletion. However, a more important factor 


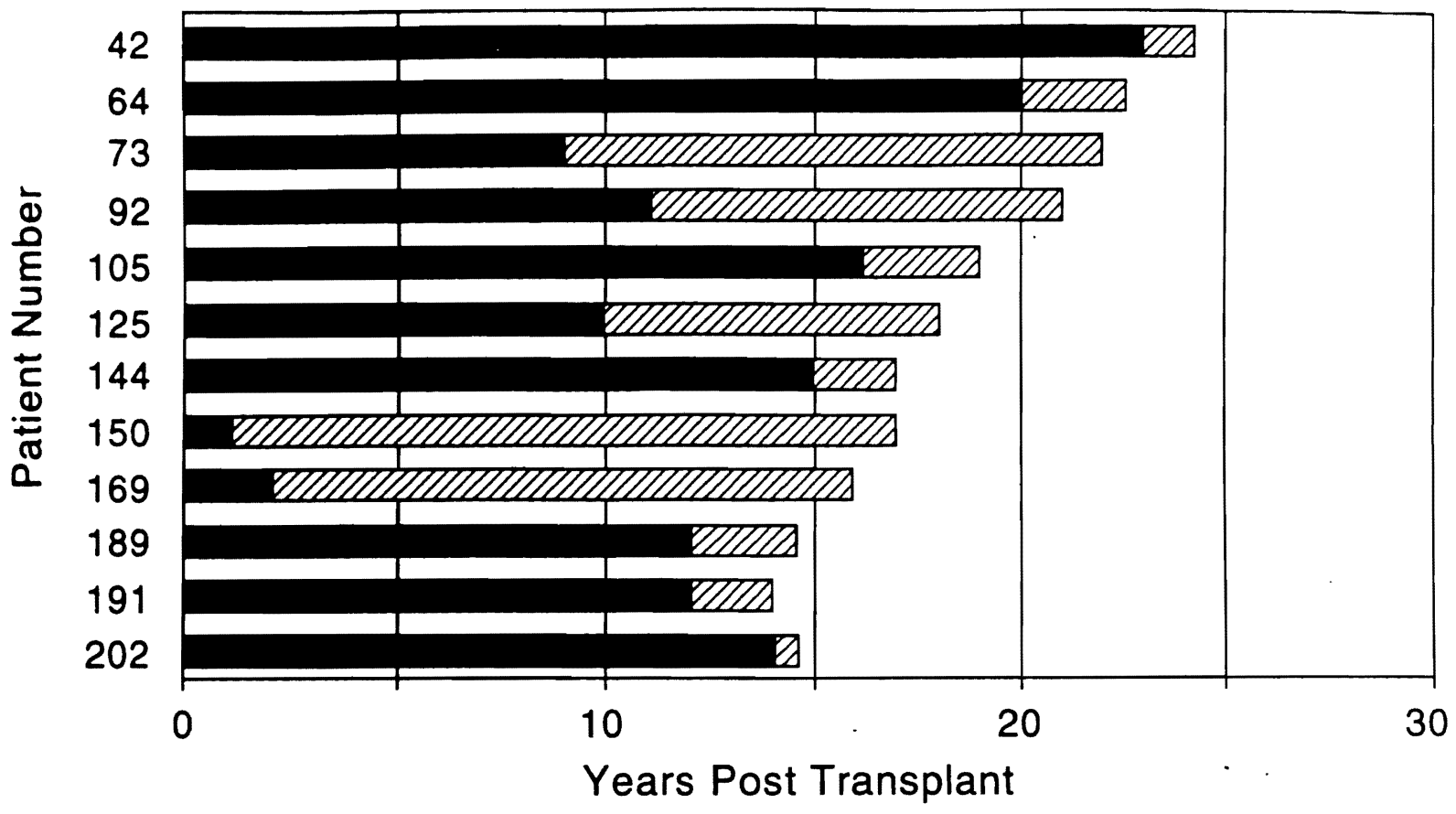

Immunosuppression $\square$ No Immunosuppression

FIG. 1. Time on and off immunosuppression (as of October 1995) of 12 long surviving liver recipients. Patients 150 and 169 stopped medication less than 2 years posttransplantation because of noncompliance. The others were weaned because of complications of chronic immunosuppression. These 12 patients represented $28 \%$ of the 42 patients in our total experience who had continuously borne hepatic allografts for 15 to almost 26 years. Four years later, these patients remain drug free. Data from ref. 16.

appears to have been a lack of understanding about the role of the organ's "passenger leukocytes."

Passenger leukocytes are of bone marrow origin, and have been known for more than 3 decades to be the principal immunogenic component of allografts. ${ }^{75-79}$ Consequently, one explanation of organ engraftment was that it involved the destruction of the immunogenic donor leukocytes by the recipient immune system, with selective sparing of the specialized parenchymal cells. The disappearance of most of the resident donor leukocytes and their replacement by recipient cells of the same lineages had been reported in 1969 in the first long-surviving human liver allografts. ${ }^{31,80}$ Because this was considered for the next 2 decades to be a unique feature of the liver allograft, the passenger leukocyte replacement became a candidate co-factor for hepatic tolerogenicity. 45.58 However, when the same cell replacement was demonstrated in intestinal allografts in $1991^{22,81}$ (Fig. 3, lower graph), it was obvious that it probably was a generic phenomenon, that is, it occurred in all successfully transplanted organs. This was promptly confirmed.

Exemplifying the power of ossified dogma, however, the possibility was not generally entertained, even at this late time, that the missing donor leukocytes had simply migrated and survived in the recipient. Consequently, organ engraftment continued to be explained by hypotheses in which donor leukocyte chimerism played no role. The hypotheses included the presence or development of suppressor, veto, and other immune regulatory cells; cytokine profile changes; a role for various idiotypic and/or enhancing antibodies; and failure of delivery of a second (co-stimulatory) signal following primary antigen presentation.

\section{AN EPIPHANY}

The requirement for nonchimerism mechanisms was eliminated when a link was established in 1992 between organ transplantation and classical neonatal and/or bone marrow transplant-induced tolerance. Using sensitive immunocytochemical and polymerase chain reaction (PCR) techniques, low level (micro) chimerism was detected in the tissues or blood of all 30 human organ recipients studied 2.5 to 30 years after transplantation of continuously functioning liver ( $\mathrm{n}=$ 25 ) or kidney allografts $(n=5) .^{70,82-85}$

From this finding, it was deduced that organ engraftment was a dynamic process that had begun at the time of transplantation with "... . widespread responses of coexisting donor and recipient immune responses, each to the other, causing reciprocal clonal expansion followed by peripheral clonal deletion." 70,82 Although 


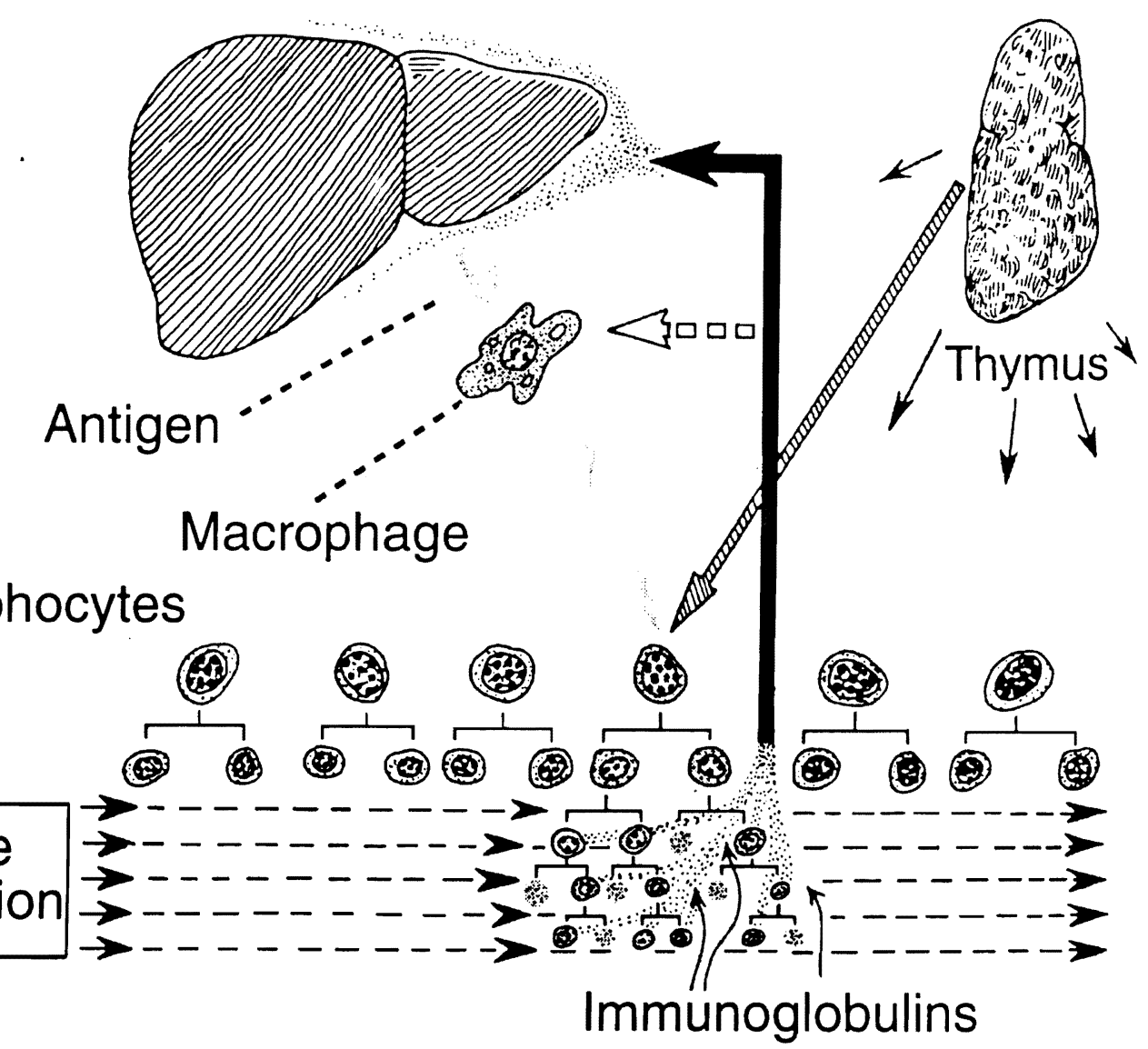

FIG. 2. Original caption published in 1969: "Hypothetical mechanisms by which nonspecific immunosuppression may lead to selective abrogation of the host immune response. Special susceptibility to these agents of a fraction of the lymphoid population could lead to exhaustion of a clone and, hence, tolerance. Since maintenance of such cell lines, even in adult life, is apparently thymic dependent in experimental animals, thymectomy would be expected to aid the process; this appears to be true in radents, but such an effect of thymus removal has not been detected in dogs or humans." Note that antigen presentation was depicted via the macrophages rather than by the dendritic cells (which were not described until 4 years later. ${ }^{74}$ The principal gap in the 1969 hypothesis was the failure to stipulate the location of the immune activation (by permission of WB Saunders).

there had been 'only one study with substantive evidence that clonal exhaustion-deletion actually existed, ${ }^{86}$ numerous confirmatory reports have been published since. ${ }^{87-92}$ Moreover, the critical importance of acute clonal exhaustion-deletion has been confirmed directly in experimental heart and liver transplantation models. ${ }^{47,53,93}$

The persistence of the disseminated donor leukocytes for as long as 3 decades implied (as was subsequently proved ${ }^{94,95}$ ) that precursor or stem cells are included in the organ's passenger leukocytes. After organ transplantation, donor leukocytes briefly constitute $1 \%$ to $20 \%$ of the recipient circulating mononuclear cells (Fig. 3, upper graph). Although the number of the donor cells is greatest with transplantation of leukocyterich organs (e.g., the liver), the same events on a smaller scale occur with transplantation of the kidney and heart. 46

Whatever the organ, the donor cells are multilineage, and include many of the dendritic cells
(DCs) ${ }^{46,48,70,82,96-98}$ that previously had been associated with antigenicity and rejection ${ }^{99,100}$ rather than tolerance. Individual samples from organ recipients often do not contain donor leukocytes, which wax and wane. ${ }^{101,102}$ However, disseminated donor cells including DCs, or other lineages, are consistently demonstrable if host non-lymphoid and lymphoid tissues and blood samples are thoroughly studied in rodents bearing long-term grafts. ${ }^{46,48,103}$

Thus, it had become obvious that both the engrafted organ and the recipient become genetic composites (Fig. 4A). It also has been established that the extent of donor leukocyte chimerism in the recipient is reflected or exceeded by the quantity of donor leukocytes in the graft. 96,104 In fact, Sakamoto et al. ${ }^{105}$ have shown that the organ allograft, whose parenchymal cells are syngeneic to the donor passenger leukocytes, provides the optimal microenvironment for donor leukocytes including the precursor and stem cells that presumably are responsible for the multilineage nature of micro- as well 


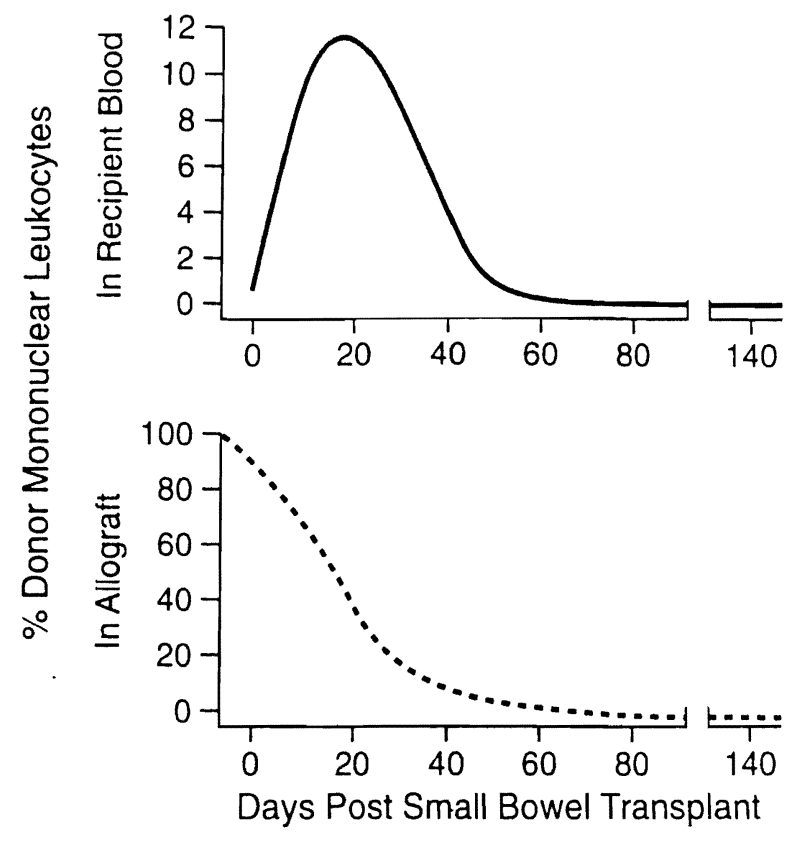

FIG. 3. The dynamic events after transplantation of all organs, exemplified here by intestinal engraftment. Upper Panel: The surge of migratory donor mononuclear leukocytes in the recipient blood during the first 2 or 3 weeks posttransplantation. Lower Panel: The contemporaneous disappearance of the passenger leukocytes from the allograft: these were replacedby recipient cells of the same lineages (schematically redrawn from data in Iwaki et al [81]). (Reprinted from Starzl et al. Transplant Proc 1999;31:1406-1411, with permission.)

as macrochimerism. ${ }^{48,96}$ Therefore, the organ allograft may be a critical site from which donor leukocytes*are renewed and exported to destinations in the host. ${ }^{105}$

A mirror image condition exists after bone marrow transplantation in which the dominant cell population is donor 106 (Fig. 4B). As demonstrated by Przepiorka et al. 107 and by Wessman et al., 108 a trace residual population of host leukocytes can be found in essentially all stable human bone marrow recipients who previously had been thought to have complete donor leukocyte chimerism.

\section{PREVIOUS ENIGMAS}

In the context developed with this new information, the donor and host leukocytes in organ recipients respond reciprocally (i.e., they mount HVG and GVH responses), and also can present antigen and induce variable degrees of specific non-reactivity (tolerance) ${ }^{16,46,70,82-84,106,109}$ (Fig. 5). If a significant level of mutual tolerance does not occur, one of the immune competent populations will destroy the other, this may be manifested at one extreme by rejection, at the other by graft-versus-host disease (GVHD), or by some combination of the 2 kinds of responses ${ }^{46,109}$ (Fig. 5). The time course of the tolerance induction is highly variable. However, the progression from the immunologic confrontation to either early or delayed graft loss, or to a variable stable state of graft acceptance (with or without immunosuppression), is monitored clinically by serial changes in organ allograft function.

The dynamic modulation of the two immunocompetent leukocyte populations, each by the other, readily explains the poor progniostic value of human leukocyte antigen (HLA) matching for any kind of organ transplantation $70,82,110$ and especially transplantation of the leukocyte-rich liver. ${ }^{111,112}$ The nullification effect also explains why GVHD rarely occurs after transplantation of immunologically active organs such as the intestine and liver, providing the recipients have not been conditioned with cytoablation and do not have underlying im-
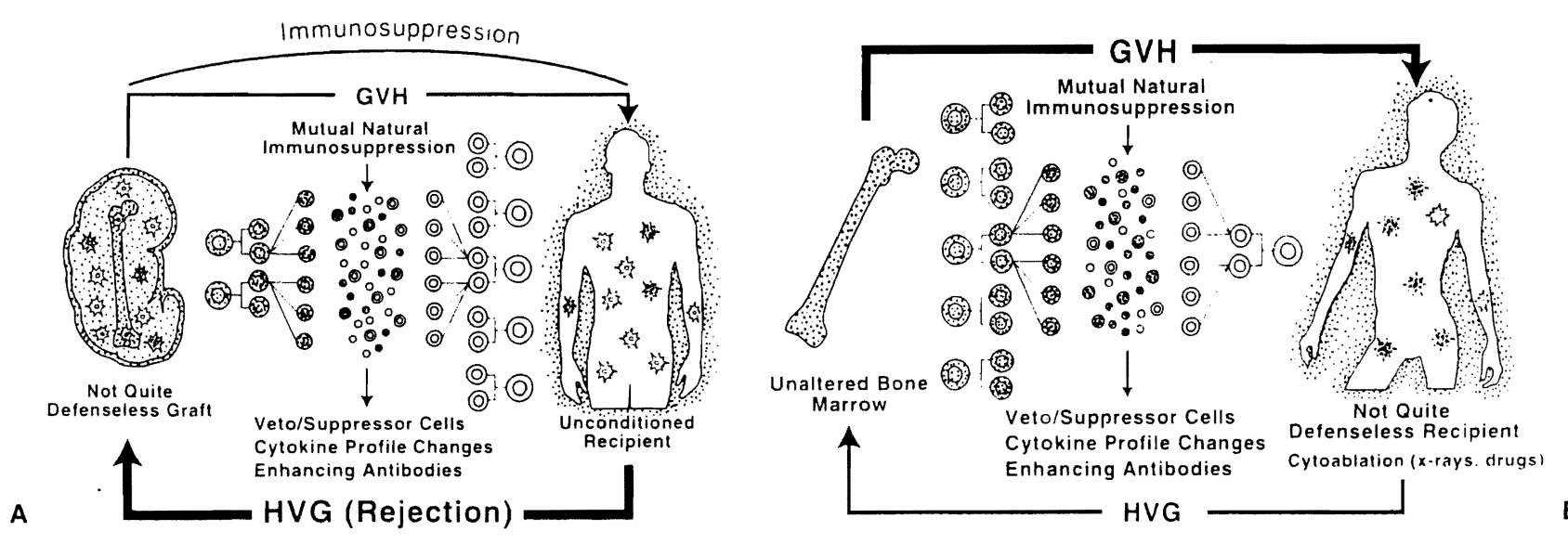

FIG. 4. Paradigm in which transplantation is seen as a bidirectional and mutually cancelling immune reaction that is (A) predominantly host-versus-graft (HVG) with whole organ grafts, and (B) predominantly graft-versus-host (GVH) with bone marrow grafts. The persistence of the minority leukocyte population after both kinds of transplantation was not recognized until the 1990 s (see text). Importantly, both the recipient and the allograft after organ transplantation contain a donor and host mixture of immune cells (i.e., leukocytes) and are therefore genetic composites (i.e., chimeric). 


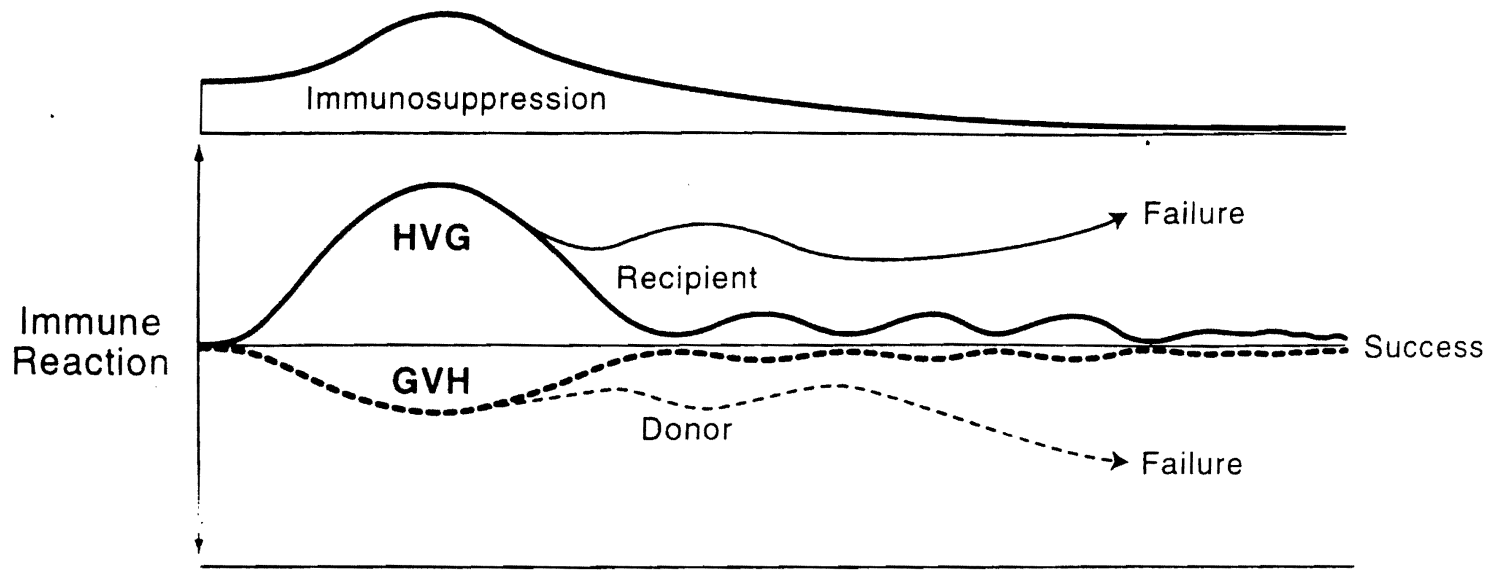

Time after Transplantation

FIG. 5. Contemporaneous host-versus-graft (HVG) and graft-versus-host (GVH) reactions after transplantation. Failure is defined as the inability to control rejection, GVHD, or sometimes both. Acute reciprocal clonal exhaustion after successful transplantation is maintained subsequently by chimerism-dependent low-grade stimulation of both leukocyte populations. The responses may wax and wane.

mune deficiency disorders. Deletion of the host arm by cytoablation, as is routinely done before clinical bone marrow transplantation, shifts immune dominance to the donor hematolymphopoietic cells, predisposes the recipient to GVHD, and is responsible for essentially all of the disparities between bone marrow transplantation and organ transplantation (Table 2).

It also was apparent why the liver is more tolerogenic than other organs. The leukocyte load contained in the normal liver is many times greater than that carried by any other organ, and it contains a larger proportion of immature precursor cells and cells of myeloid lineage. ${ }^{46}$ As a corollary, it was predicted that recipients of organs less well-endowed with leukocytes could be safely infused with adjunct donor bone marrow cells (BMC). ${ }^{113-115}$ In practice, BMC infusion has been shown to be safe in such patients and even in recipients of liver and intestinal allografts. However, the need to provide the same immunosuppression as for conventional transplantation of the various organs has imposed

TABLE 2. Differences between Clinical Organ Transplantation and Bone Marrow Transplantation

\begin{tabular}{lll}
\hline Feature & $\begin{array}{c}\text { Organ } \\
\text { Transplantation }\end{array}$ & $\begin{array}{c}\text { Bone Marrow } \\
\text { Transplantation }\end{array}$ \\
\hline Host cytoablation & No & Yes* \\
HLA matching & Not essential & Critical \\
Principal complication & Rejection & $\begin{array}{c}\text { Graft-versus- } \\
\text { host disease }\end{array}$ \\
Immunosuppression-free & Uncommon & Common \\
Term for success & Acceptance & Tolerance \\
\hline
\end{tabular}

*This therapeutic step allows a relatively unopposed graft-versus-host reaction and accounts for the other differences. a fundamental limitation on the efficacy of the adjunct BMC strategy (see discussion below).

Finally, the ostensible differences between the adaptive immune response to allografts and the analogous response to microorganisms were explained by the double immune reaction after transplantation versus the single host versus pathogen response of infections. $\mathrm{Mi}-$ croorganisms that induce an MHC-restricted adaptive immune response are generally intracellular, and have no or low cytopathic qualities. ${ }^{116-118}$ Host cytolytic T lymphocytes recognize only microorganism-derived peptides that are presented in the context of host MHC molecules. Because elimination of all the infected cells could disable or even kill the host, the mechanism of clonal exhaustion-deletion has evolved with which the immune response can be tempered or terminated, allowing both host and pathogen to survive. ${ }^{109,116-120}$

The highly variable clinical manifestations of clonal exhaustion-deletion in a patient infected with disseminated non-cytopathic microorganisms (e.g., the common hepatitis viruses) versus the clinical findings in the organ recipient are shown in Figure 6A-C. In one scenario, the pathogen (antigen) load may rapidly increase during the so-called latent period, but then be dramatically and efficiently reduced by antigen-specific effector T-cells. Following control of the infection, the cytotoxic T lymphocytes (CTL) subside (Fig. 6B). The events are similar to those of irreversible organ rejection (or rarely GVHD) in the unmodified or ineffectively treated recipient (Fig. 6, subtext of panel B).

Alternatively, however, such infections may lead to a continuously high antigen load and an antigen specific immunologic collapse (Fig. 6A). The resulting asymptomatic carrier state is analogous to unqualified accep- 


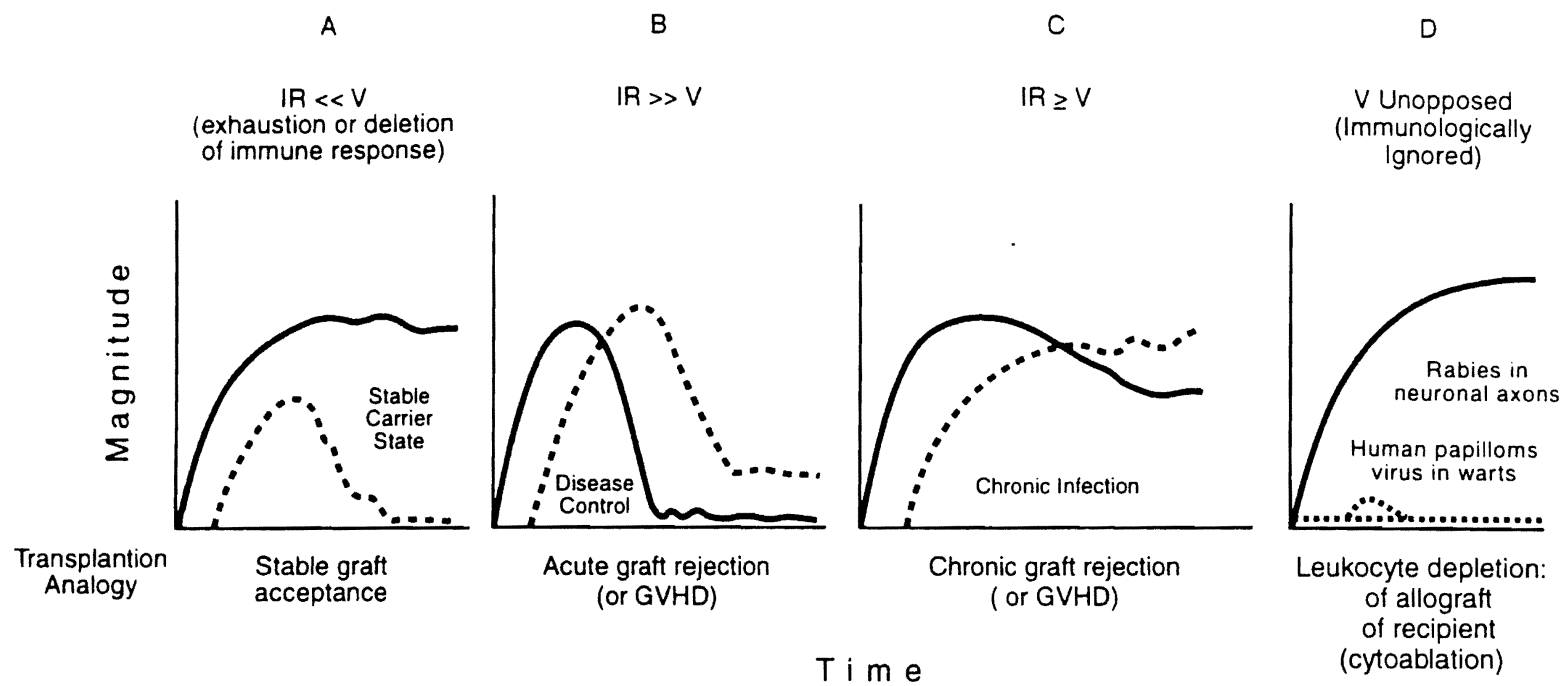

FIG. 6. Potential outcomes after infection with non-cytopathic microorganisms and analogies (expressed as Rejection or graft-versus-host disease) to organ and bone marrow transplantation. The horizontal axis denotes time. The vertical axis shows the magnitude of the viral load ( $\mathrm{v}$, solid line), and the host immune response (IR, dashed line).

tance of an allograft. This kind of result after transplantation, which may include independence from immunosuppression, is not often achieved by organ recipients and usually is associated with donor-recipient compatibility of HLA alleles (a good tissue match). Complete tolerance induced by an organ is a mirror image version of successful bone marrow transplantation (Figs. 4 and 5; also compare panel A [organ-induced tolerance] with panel D [BMC-induced tolerance in a cytoablated recipient]).

Between the 2 extremes of destructive (protective) immunity and a carrier (tolerant) state, a persistent infectious agent may induce an unrelenting immune response that results in serious immunopathology such as the chronic active hepatitis following a $\mathrm{B}$ or $\mathrm{C}$ virus infection. This is equivalent to chronic rejection (or uncommonly GVHD) after liver transplantation (Fig. 6C). Chronic rejection may range from aggressive to indolent, despite the best immunosuppression available today.

\section{IMMUNE REGULATION}

We have proposed that the HVG and GVH responses of transplantation as well as the responsiveness or unresponsiveness to the antigens of pathogens, tumors, and self are governed by the migration and localization of the respective antigens. 109 The donor passenger leukocytes represent the only mobile donor antigen in an organ allograft that is capable of reaching hostlymphoid organs in làrge quantity. After organ transplantation, the donor leukocytes migrate hematogenously to the recipient lymphoid organs ${ }^{121-123}$ (see Fig. 3 ) where they may induce and exhaust antigraft $T$ cells while activated donor antihost $\mathrm{T}$ cells are deleted. ${ }^{109}$ If the respective donor and recipient alloantigens do not have access to organized lymphoid collections (epitomized by but not limited to the lymphoid organs) HVG and GVH cytotoxic $\mathrm{T}$ cell responses either are not induced (immune indifference) or cannot be sustained. ${ }^{109,116-118.124}$ Thus, the only 2 mechanisms needed to explain all permutations of immune responsiveness or non-responsiveness are clonal exhaustion-deletion and immune indifference.

Once initiated, termination of the immune response occurs by 2 kinds of apoptosis, each with distinct molecular pathways (reviewed by Lenardo ${ }^{125}$ ). If one leukocyte population eliminates the other, its antigenspecific clonal expansion ceases, stopping the secretion of IL2 and other pro inflammatory molecules (corresponding to Fig. 6B). The ensuing "passive" apoptosis of the cytokine-deficient clone requires new protein synthesis, is strongly inhibited by $\mathrm{Bc} 1-2$ and related anti-apoptotic molecules, and is thought to involve mitochondrial apoptosis mechanisms rather than the death cytokines such as Fas ligand (FasL) and tumor necrosis factor (TNF). 125

In contrast, organ engraftment occurs when the alloantigen is not eliminated and when the continuing response is terminated by apoptosis involving FasL and TNF. ${ }^{125}$ If the clonal exhaustion-deletion is complete enough, the recipient may become immunosuppressionindependent (Fig. 6A). With the partial tolerance that usually characterizes immunosuppression-dependent organ "acceptance" both kinds of apoptosis may be involved, ${ }^{126.127}$ corresponding to some version of Figure 6C.

The significance of the patchy donor leukocyte (micro) chimerism remaining after the acute post-transplant period has been questioned because of the inconsistency 
with which donor leukocytes can be found in blood or tissue samples from organ recipients; the development of acute or chronic rejection despite chimerism; and the inability to use microchimerism to guide posttransplantation drug weaning. Far from eroding the significance of microchimerism, these observations (summarized in ${ }^{128}$ ) are readily accommodated by the migration/locilization cuncept. ${ }^{46.70 .82,109}$ Mloreover, most of the ostensibly negative studies have consisted essentially of looking for chimerism in single blood samples.

With serial sampling, Terakura et al. ${ }^{129}$ have shown in a rodent allograft model that a large proportion of the donor leukocytes surviving the early post-transplant period leave the blood and lymphoid tissues during the first 60 transplant days and find niches in non-lymphoid tissues and organs of the host such as the skin, and particularly in the allograft itself. ${ }^{96,104}$ which may provide an optimal syngeneic environment for donor precursor and stem cells. ${ }^{105}$ Periodic leakage of the chimeric cells from such non-lymphoid areas to the host lymphoid compartment after transplantation has been suggested as an explanation for the maintenance of clonal exhaustion, ${ }^{109,124}$ analogous to the stable equilibrium between destructive and non-destructive immunity described by Ohashi et al. ${ }^{130,131}$ in a model of autoimmune diabetes mellitus.

In experimental animals, in which a complete search for donor cells is possible, chimerism always can be found in stable organ recipients. ${ }^{103,132}$ In contrast, the disappearance of microchimerism in an organ recipient presages loss of the outlying allograft from chronic or acute rejection. $46,98,133$ Allograft rejection was associated with thymus-dependent recovery of precursor CTL in the mouse model used by Ehl et al. ${ }^{133}$ Thus, persistence of donor leukocyte chimerism is a prerequisite for, but not synonymous with and not a consequence of, the evolution of organ-allograft acceptance under clinically relevant circumstances. ${ }^{70,82,109}$

\section{A THERAPEUTIC IMPASSE?}

It is self-evident why it has been so difficult in human organ recipients to achieve the closely related objectives of drug-free tolerance and freedom from chronic rejection, and why these objectives are achieved more frequently with the leukocyte-rich liver than with other less well endowed organ allografts. Tolerance induction, no matter what the organ, depends on the acute clonal activation induced by the migratory donor leukocytes. However, the prevention with immunosuppression of destructive immunity (i.e., rejection) for long enough to allow the variable induction of tolerance has been the sine qua non of organ transplantation. In turn, the penalty for inhibiting either the critical step of cell migration to the host lymphoid organs, or the subse- quent immune activation (immunosuppressants do both) may be the inability to ever stop drug therapy. In such cases, the reduction of maintenance immunosuppression below the threshold necessary to complement the variably incomplete tolerance, is followed by the disappearance of the donor leukocytes from the host tissues and allograft, and the development of chronic rejection (Fig. 6C).

This chain of events is seen in the majority of human recipients of long surviving organ allografts, but with the lowest incidence of chronic rejection in liver recipients. Clinical efforts to facilitate tolerance in organ recipients with adjunct donor BMC have been hampered by the fact that the same potentially antitolerogenic immunosuppression is required as that used for conventional organ transplantation. ${ }^{113}$ The low level chimerism normally found in organ recipients has been increased many fold by the additional load of donor leukocytes and has been reported in some studies to result in a higher incidence of donor specific nonreactivity. ${ }^{113-115,134}$ However, discontinuance of immunosuppression has not been achieved.

\section{DERIVATIVE FALSE DOGMAS}

The paradigm that emerged from the chimerism discoveries has necessitated reevaluation of other aspects of transplantation immunology. Studies of allogeneic tolerance mechanisms commonly has been done with "parking" techniques. ${ }^{75,76,79,135-137}$ At Stage 1, tissue or an organ is engrafted with the aid of recipient irradiation, a few post-transplant doses of an immunosuppressant or in spontaneous tolerance liver transplant models ${ }^{136,137}$ without treatment. At Stage 2 of a prototype experiment, the retransplanted allograft is not rejected by naïve animals of the original recipient strain.

It is self evident that parking experiments are inappropriate for most studies of tolerance mechanisms. Stage 1, if it is successful, is an example of tolerance induction per se, although the term tolerance has been studiously avoided by most investigators using these models. By replacing most of the passenger leukocytes with those of the strain to which the altered graft is secondarily transplanted, the essential tolerogenic step of immune activation is eliminated from the retransplantation stage. In addition, the donor strain leukocytes in the parked allografts are not uniformly replaced ${ }^{104}$ as has been commonly assumed. Furthermore, neither the residual donor cells nor the replacement cells from the recipient can be viewed as either naïve or purely in terms of antigen. Finally, completeness of graft "acceptance" during the parking or after retransplantation cannot be assumed without examining the allograft for histopathological signs of chronic rejection and without analyzing its leukocyte composition. 
The most important dogma to be questioned is the hitherto unchallenged assumption that passenger leukocytes are highly immunogenic while parenchymal cells (especially hepatocytes) are not. The immunogenicity of nonparenchymal cells has been widely attributed to the expression by these bone marrow derived leukocytes of MHC class II and/or co-stimulatory (i.e., B7) molecules. In the antigen migration/localization paradigm, ${ }^{109}$ passenger leukocytes appear to be uniquely immunogenic primarily because of their ability to migrate to lymphoid organs whereas organ parenchymal cells are non-immunogenic largely, if not entirely, because they are immobilized within the organ architecture. This would readily explain the otherwise enigmatic finding by Bumgardner and Orosz et al., ${ }^{138-140}$ that when hepatocytes are isolated and given by infusion, they are as immunogenic, if not more so, than hepatic passenger leukocytes.

Acknowledgment: This work was supported by the National Institutes of Health grants DK 29961, R01 AI/DK 38899, AI 40329, DK 49615, and R01 DK 54232 and the Juvenile Diabetes Foundation 4-1999-807.

\section{ABBREVIATIONS}

$\begin{array}{ll}\text { ALG } & \text { antilymphocyte globulin } \\ \text { BMC } & \text { bone marrow cells } \\ \text { CTL } & \text { cytotoxic T lymphocytes } \\ \text { DC } & \text { dendritic cells } \\ \text { FASL } & \text { fas ligand } \\ \text { GVH } & \text { graft versus host } \\ \text { GVHD } & \text { graft versus host disease } \\ \text { HLA } & \text { human leukocyte antigen } \\ \text { HVG } & \text { host versus graft } \\ \text { IRB } & \text { institutional review board } \\ \text { MHC } & \text { major histocompatibility complex } \\ \text { PCR } & \text { polymerase chain reaction } \\ \text { TBI } & \text { total body irradiation } \\ \text { TNF } & \text { tumor necrosis factor }\end{array}$

\section{REFERENCES}

1. Groth CG, Brent LB, Calne RY, et al. Historical landmarks in clinical transplantation: conclusions from the consensus conference held at the University of California, Los Angeles (UCLA). World J Surg 2000;24:834-843

2. Starzl TE. History of clinical transplantation. World J Surg 2000;24:759-782

3. Starzl TE, Marchioro TL, Waddell WR. The reversal of rejection in human renal hemografts with subsequent development of homograft tolerance. Surg Gynecol Obstet 1963;117:385-395

4. Starzl TE, Ishikawa M, Putnam CW, et al. Progress in and deterrents to orthotopic liver transplantation, with special reference to survival, resistance to hyperacute rejection, and biliary duct reconstruction. Transplant Proc 1974;6:129-139
5. Merrill JP, Murray JE, Harrison JH, et al. Successful homotransplantation of the kidney between non-identical twins. New Engl J Med 1960;262:1251-1260

6. Murray JE, Merrill JP, Dammin GJ, et al. Study of transplantation immunity after total body irradiation: clinical and experimental investigation. Surgery 1960;48:272-284

7. Hamburger J, Vaysse J, Crosnier J, et al. Renal homotransplantation in man after radiation of the recipient. Am J Med 1962;32: 854-871

8. Kuss R, Legrain M, Mathe G, Nedey R, Camey M. Homologous human kidney transplantation. Experience with six patients. Postgrad Med J 1962;38:528-531

9. Mannick JA, Lochte HL, Ashley CA, Thomas ED, Ferrebee JW. A functioning kidney homotransplant in the dog. Surgery 1959; 46:821-828

10. Murray JE, Merrill JP, Harrison JH, Wilson RE, Dammin GJ. Prolonged survival of human-kidney homografts by immunosuppressive drug therapy. New Engl J Med 1963;268:13151323

11. Murray JE, Wilson RE, O'Connor NE. Evaluation of longfunctioning human kidney transplants. Surg Gynecol Obstet 1967;124:509-520

12. Calne RY. Inhibition of the rejection of renal homografts in dogs by purine analogues. Transplant Bull 1961;28:445-461

13. Calne RY, Alexandre GPJ, Murray JE. A study of the effects of drugs in prolonging survival of homologous renal transplants in dogs. Ann NY Acad Sci 1962;99:743-761

14. Calne R, Friend P, Moffatt $S$, et al. Prope tolerance, perioperative Campath $\mathrm{IH}$, and low-dose cyclosporin monotherapy in renal allograft recipients. Lancet 1998;351:1701-1702

15. Calne R, Moffatt SD, Friend PJ, et al. Campath IH allows lowdose cyclosporine monotherapy in 31 cadaveric renal allograft recipients. Transplantation 1999;68:1613-1616

16. Starzl TE, Demetris AJ, Murase N, et al. The lost chord: Microchimerism. Immunol Today 1996;17:577-584;588

17. Starzl TE, Marchioro TL, Von Kaulla KN, et al. Homotransplantation of the liver in humans. Surg Gynecol Obstet 1963;117: 659-676

18. Starzl TE, Groth CG, Brettschneider L, et al. Orthotopic homotransplantation of the human liver. Ann Surg 1968;168:392-415

19. Starzl TE, Marchioro TL, Hutchison DE, et al. The clinical use of antilymphocyte globulin in renal homotransplantation. Transplantation 1967;5:1100-1105

20. Starzl TE, Kaupp HA Jr, Brock DR, Butz GW Jr, Linman JW. Homotransplantation of multiple visceral organs. Am J Surg 1962;103:219-229

21. Murase N, Demetris AJ, Kim DG, et al. Rejection of the multivisceral allografts in rats: a sequential analysis with comparison to isolated orthotopic small bowel and liver grafts. Surgery 1990;108:880-889

22. Murase N, Demetris AJ, Matsuzaki T, et al. Long survival in rats after multivisceral versus isolated small bowel allotransplantation under FK 506. Surgery 1991;110:87-98

23. Starzl TE, Marchioro TL, Porter KA, et al. Factors determining short- and long-term survival after orthotopic liver homotransplantation in the dog. Surgery 1965;58;131-155

24. Starzl TE. Efforts to Mitigate or Prevent Rejection. In: Experience in Hepatic Transplantation. Philadelphia: WB Saunders; 1969;203-206

25. Cordier G, Garnier H, Clot JP, et al. La greffe de foie orthotopique chez le porc. Mem Acad Chir (Paris) 1966;92:799807

26. Peacock JH, Terblanche J. Orthotopic homotransplantation of the liver in the pig. In: Read AE, ed. The Liver. London: Butterworth; 1967:333

27. Calne RY, White HJO, Yoffa DE, et al. Observations of orthotopic liver transplantation in the pig. Br Med J 1967;2:478-480 
28. Calne RY, White HJO, Yoffa DE, et al. Prolonged survival of liver transplants in the pig. Br Med J 1967;4:645-648

29. Starzl TE. Rejection in Unmodified Animals. In: Experience in Hepatic Transplantation. Philadelphia: WB Saunders; 1969:184

30. Hunt AC. Pathology of liver transplantation in the pig. In: Read AE, ed. The Liver. London: Butterworth; 1967:337

31. Porter KA. Pathology of the orthotopic homograft and heterograft. In: Experience in Hepatic Transplantation. Starzl TE, ed. Philadelphia: WB Saunders; 1969:422-471

32. Billingham RE, Brent L, Medawar PB. "Actively acquired tolerance" of foreign cells. Nature 1953;172:603-606

33. Billingham R, Brent L, Medawar P. Quantitative studies on tissue transplantation immunity. III. Actively acquired tolerance. Philos Trans R Soc Lond (Biol) 1956;239:357-412

34. Main JM, Prehn RT. Successful skin homografts after the administration of high dosage $\mathrm{X}$ radiation and homologous bone marrow. J Natl Cancer Inst 1955; 15:1023-1029

35. Mathe G, Amiel JL, Schwarzenberg L, Cattan A, Schneider M. Haematopoietic chimera in man after allogenic (homologous) bone-marrow transplantation. Brit Med J 1963;2:1633-1635

36. Gatti RA, Meuwissen HJ, Allen HD, Hong R, Good RA. Immunological reconstitution of sex-linked lymphopenic immunological deficiency. Lancet 1968;2:1366-1369

37. Bach FH. Bone-marrow transplantation in a patient with the Wiskott-Aldrich syndrome. Lancet 1968;2:1364-1366

38. Thomas Ed. Allogeneic marrow grafting: a story of man and dog. In: Terasaki PI, ed. History of Transplantation: Thirty-Five Recollections. Los Angeles, CA: UCLA Tissue Typing Laboratory; 1991:379-393

39. Calne RY, Sells RA, Pena Jr., et al. Induction of immunological tolerance by porcine liver allografts. Nature 1969;223:472-474

40. Kamada N, Brons G, Davies HffS. Fully allogeneic liver grafting in rats induces a state of systemic nonreactivity to donor transplantation antigens. Transplantation 1980;29:429-431

41. Kamada N, Davies HffS, Roser B. Reversal of transplantation immunity by liver grafting. Nature 1981;292:840-842

42. Zimmerman FA, Davies HS, Knoll PP, Gocke JM, Schmidt T. Orthotopic liver allografts in the rat. Transplantation 1984;37: 406-410

43. Houssin D, Gigou M, Franco D, et al. Specific transplantation tolerance induced by spontaneously tolerated liver allograft in inbred strains of rat. Transplantation 1980;29:418-419

44. Engemann R, Ulrichs K, Thiede A, Muller-Ruchholtz W, Hamelmann $\mathrm{H}$. Value of a physiological liver transplant model in rats. Induction of specific graft tolerance in a fully allogeneic strain combination. Transplantation 1982;33:566-568

45. Murase N, Kim DG, Todo S, et al. FK 506 suppression of heart and liver allograft rejection II: the induction of graft acceptance in rat. Transplantation 1990;50:739-744

46. Murase N, Starzl TE, Tanabe M, et al. Variable chimerism, graft versus host disease, and tolerance after different kinds of cell and whole organ transplantation from Lewis to Brown-Norway rats. Transplantation 1995;60:158-171

47. Bishop GA, Sun J, DeCruz DJ, et al. Tolerance to rat liver allografts. III. Donor cell migration and tolerance-associated cytokine production in peripheral lymphoid tissues. J Immunol 1996; 156:4925-4931

48. Qian S, Demetris AJ, Murase N, Rao AS, Fung JJ, Starzl TE. Murine liver allograft transplantation: tolerance and donor cell chimerism. Hepatology 1994;19:916-924

49. Lu L, Woo J, Rao AS, et al. Propagation of dendritic cell progenitors from normal mouse liver using GM-CSF and their maturational development in the presence of type-I collagen. J Exp Med 1994;179:1823-1834

50. Dahmen U, Qian S, Rao AS, et al. Split tolerance induced by orthotopic liver transplantation in mice. Transplantation 1994; $58: 1-8$
51. Lu L, Rudert WA, Qian S, et al. Growth of donor-derived dendritic cells from the bone marrow of murine liver allograft recipients in response to granulocyte/macrophage colony-stimulating factor. J Exp Med 1995;182:379-387

52. Rastellini C, Lu L, Ricordi C, et al. GM-CSF stimulated hepatic dendritic cell progenitors prolong pancreatic islet allograft survival. Transplantation 1995;60:1366-1370

53. Qian S, Lu L, Fu F, et al. Apoptosis within spontaneously accepted mouse liver allografts: evidence for deletion of cytotoxic $\mathrm{T}$ cells and implications for tolerance induction. J Immunol 1997;158:4654-4661

54. Khanna A, Moreli AF, Zhong C, et al. Effects of liver-derived dendritic cell progenitors on $\mathrm{Th} 1$ and Th2-like cytokine responses in vitro and in vivo. J Immunol 2000;164:1346-1354

55. Davies HS, Kamada N, Roser BJ. Mechanisms of donor-specific unresponsiveness induced by liver grafting. Transplant Proc 1983; 15:831-835

56. Crispe N, Mehal WZ. Strange brew: $T$ cells in the liver. Immunology Today 1996; 17:522-525

57. Singh PB, Brown RF, Roser BJ. Class I transplantation antigens in solution in body fluids and in the urine. J Exp Med 1988; 168:195

58. Sumimoto R, Kamada N. Specific suppression of allograft rejection by soluble class I antigen and complexes with monoclonal antibody. Transplantation 1990;50:678-682

59. Davies HffS, Pollard SG, Calne RY. Soluble HLA antigens in the circulation of liver graft recipients. Transplantation 1989;47: 524-527

60. Calne R, Davies H. Organ graft tolerance: the liver effect. Lancet 1994;343:67-68

61. Calne RY, Watson CJE, Brons IGM, et al. Tolerance of porcine renal allografts induced by donor spleen cells and seven days' treatment with cyclosporine. Transplantation 1994;57:14331435

62. Qian S, Fu F, Li Y, et al. Presensitization by skin grafting from MHC class I or class II deficient mice identifies class I antigens as inducers of allosensitization. Immunology 1995;85:82-87

63. Corry RJ, Winn HJ, Russell PS. Primary vascularized allografts of hearts in mice. The role of $\mathrm{H}-2 \mathrm{D}, \mathrm{H}-2 \mathrm{~K}$ and non-H-2 antigens in rejection. Transplantation 1973;16:343-350

64. Russell PS, Chase CM, Colvin RB, Plate JMD. Kidney transplants in mice: an analysis of the immune status of mice bearing long-term H-2 incompatible transplants. J Exp Med 1978;147: $1449-1468$

65. Schwartz R, Damashek W. Drug induced immunologic tolerance. Nature (London) 1959;183:1682-1683

66. Simonsen M. On the acquisition of tolerance by adult cells. Ann NY Acad Sci 1960;87:382-390

67. Sterzl J, Silverstein AM. Development aspects of immunity. Adv Immunol 1967;6:337-459

68. Dresser DW, Mitchison NA. The mechanism of immunological paralysis. Adv Immunol 1998;8:129-181

69. Starzl TE. Host Graft Adaptation. In: Experience in Renal Transplantation. Philadelphia: WB Saunders; 1964:168-170

70. Starzl TE, Demetris AJ, Trucco M, et al. Cell migration and chimerism after whole-organ transplantation: the basis of graft acceptance. Hepatology 1993;17:1127-1152

71. Ramos HC, Reyes J, Abu-Elmagd K, et al. Weaning of immunosuppression in long term liver transplant recipients. Transplantation 1995;59:212-217

72. Mazariegos GV, Reyes J, Marino I, et al. Weaning of immunosuppression in liver transplant recipients. Transplantation 1997; 63:243-249

73. Starzl TE. Efforts to mitigate or prevent rejection: In: Experience in Hepatic Transplantation. Philadelphia: WB Saunders; 1969:228-233

74. Steinman RM, Cohn ZA. Identification of a novel cell type in 
peripheral lymphoid organs of mice. 1. Morphology, quantitation, tissue distribution. J Exp Med 1973;137:1142-1162

75. Steinmuller D. Immunization with skin isografts taken from tolerant mice. Science 1967;158:127-129

76. Elkins WL, Guttmann RD. Pathogenesis of a local graft versus host reaction: immunogenicity of circulating host leukocytes. Science 1968;159:1250-1251

77. Talmage DW, Dart G, Radovich J, Lafferty KJ. Activation of transplant immunity: effect of donor leukocytes on thyroid allograft rejection. Science 1976;191:385-387

78. Lafferty KJ, Prowse SJ, Simeonovic CJ. Immunobiology of tissue transplantation: a return to the passenger leukocyte concept. Ann Rev Immunol 1983;1:143-173

79. Lechler RI, Batchelor JR. Restoration of immunogenicity to passenger cell-depleted kidney allografts by the addition of donorstrain dendritic cells. J Exp Med 1982;155:31-41

80. Kashiwagi N, Porter KA, Penn I, Brettschneider L, Starzl TE. Studies of homograft sex and of gamma globulin phenotypes after orthotopic homotransplantation of the human liver. Surg Forum 1969;20:374-376

81. Iwaki Y, Starzl TE, Yagihashi A, et al. Replacement of donor lymphoid tissue in human small bowel transplants under FK 506 immunosuppression. Lancet 1991;337:818-819

82. Starzl TE, Demetris AJ, Murase $\mathrm{N}$, et al. Cell migration, chimerism, and graft acceptance. Lancet 1992;339:15791582

83. Starzl TE, Demetris AJ, Trucco M, et al. Systemic chimerism in human female recipients of male livers. Lancet 1992;340: 876-877

84. Starzl TE, Demetris AJ, Trucco M, et al. Chimerism after liver transplantation for type IV glycogen storage disease and Type I Gaucher's disease. N Engl J Med 1993;328:745-749

85. Starzl TE, Demetris AJ, Trucco M, et al. Chimerism and donorspecific nonreactivity 27 to 29 years after kidney allotransplantation. Transplantation 1993;55:1272-1277

86. Webb S, Morris C, Sprent J. Extrathymic tolerance of mature T cells: clonal elimination as a consequence of immunity. Cell 1990;63:1249-1256

87. Matzinger P. Tolerance, danger, and the extended family. Ann Rev Immunol 1994;12:991-1045

88. Moskophidis D, Lechner F, Pircher H, Zinkernagel RM. Virus persistence in acutely infected immunocompetent mice by exhaustion of antiviral cytotoxic effector T cells. Nature 1993;362: 758-761

89. Critchfield J, Racke M, Zuniga-Pflucker J, et al. T cell deletion in high antigen dose therapy of autoimmune encephalomyelitis. Science 1994;263:1139-1143

90. Aichele P, Brduscha-Riem K, Zinkernagel RM, Hengartner $H$, Pircher $H$. T cell priming versus $T$ cell tolerance induced by synthetic peptides. J Exp Med 1995; 182:261-266

91. Hotchin J. Biology of lymphocytic choriomeningitis infection: Virus induced immune disease. Cold Spr Harbor Symp Quantitative Biology 190,..37:479-499

92. Ridge JP, Fuchs EJ, Matzinger P. Neonatal tolerance revisited: turning on newborn $\mathrm{T}$ cells with dendritic cells. Science 1996;271:1723-1726

93. Lu L, Li W. Zong C. et al. Increased apoptosis of immunoreactive host cells and augmented donor leukocyte chimerism, not sustained inhibition of B7 molecule expression are associated with prolonged cardiac allograft survival in mice preconditioned with immature donor dendritic cells plus anti-CD40L mAb. Transplantation 1999;68:747-757

94. Murase N, Starzl TE, Ye Q, et al. Multilineage hematopoietic reconstitution of supralethally irradiated rats by syngeneic whole organ transplantation: with particular reference to the liver. Transplantation 1996;61:1-4

95. Taniguchi H, Toyoshima T, Fukao K, Nakauchi H. Presence of hematopoietic stem cells in the adult liver. Nature Medicine 1996;2:198-203

96. Demetris AJ, Murase N, Fujisaki S, et al. Hematolymphoid cell trafficking, microchimerism, and GVH, reactions after liver, bone marrow, and heart transplantation. Transpl Proc 1993;25: 3337-3344

97. Murase N, Demetris AJ, Woo J. et al. Lymphocyte traffic and graft-versus-host disease after fully allogeneic small bowel transplantation. Transpl Proc 1991;23:3246-3247

98. Demetris AJ, Murase N, Starzl TE. Donor dendritic cells after liver and heart allotransplantation under short-term immunosuppression. Lancet 1992;339:1610

99. Steinman RM. The dendritic cell system and its role in immunogenicity. Annu Rev Immunol 1991;9:271-296

100. Thomson AW, Lu L, Murase N, et al. Microchimerism, dendritic cell progenitors and transplantation tolerance. Stem Cells 1995; 13:622-639

101. Rudert WA, Kocova M, Rao A, Trucco M. Fine quantitation by competitive PCR of circulating donor cells in post-transplanted chimeric recipients. Transplantation 1994;58:964-965

102. Hisanaga M, Hundrieser J, Boker K, et al. Development, stability, and clinical correlations of allogeneic microchimerism after solid organ transplantation. Transplantation 1996;61:40-45

103. Murase N, Demetris AJ, Tsamandas AC, Ye Q, Starzl TE. The heterogenous distribution of chimerism produced by rat organ and bone marrow allotransplantation. Transplantation 1996;61: $1126-1131$

104. Ichikawa N, Demetris AJ, Starzl TE, et al. Donor and recipient leukocytes in organ allografts of recipients with variable donorspecific tolerance: with particular reference to chronic rejection. Liver Transplant 2000;6:686-702

105. Sakamoto T, Ye Q, Lu L, et al. Donor hematopoietic progenitor cells in nonmyeloablated rat recipients of allogeneic bone marrow and liver grafts. Transplantation 1999;67:833-840

106. Starzl TE, Demetris AJ. Transplantation milestones: viewed with one- and two-way paradigms of tolerance. JAMA 1995; 273:876-879

107. Przepiorka D, Thomas ED, Durham DM, Fisher L. Use of a probe to repeat sequence of the $\mathrm{Y}$ chromosome for detection of host cells in peripheral blood of bone marrow transplant recipients. Am J Clin Pathol 1991;95:201-206

108. Wessman M, Popp S, Ruutu T, et al. Detection of residual host cells after bone marrow transplantation using non-isotopic in situ hyubridization and karyotype analysis. Bone Marrow Transplant 1993;11:279-284

109. Starzl TE, Zinkernagel ZR. Antigen localization and migration in immunity and tolerance. N Eng J Med 1998;339:1905-1913

110. Starzl TE, Rao AS, Trucco M, et al. Explanation for loss of the HLA matching effect. Transplant Proc 1995;27:57-60

111. Markus BH, Duquesnoy RJ, Gordon RD, et al. Histocompatibility and liver transplant outcome. Does HLA exert a dualistic effect? Transplanttaion 1998;46:372-377

112. Donaldson P, Underhill J, Doherty D, et al. Iniluence of human leukocyte antigen matching on liver allograft survival and rejection: "the dualistic effect." Hepatology 1993;17:1008-1015

113. Fontes P, Rac A, Demetris JA, Zeevi A, et al. Augmentation with bone marrow of donor leukocyte migration for kidney. liver, heart, and pancreas islet transplantation. Lancet 1994:344: $151-155$

114. Rao AS, Fontes P, Dodson F, et al. Augmentation of natural chimerism with donor bone marrow in orthotopic liver recipients. Transplant Proc 1996;28:2959-2965

115. Garcia Morales R, Esquenazi V, Zucker K. et al. Assessment of the effects of cadaver donor bone marrow on kidney allograft recipient blood cell chimerism by a novel technique combining PCR and flow cytometry (PCR-FLOW). Transplantation 1996;62:1149-1160 
116. Zinkernagel RM. Immunology taught by viruses. Science 1996; 271:173-178

117. Zinkernagel RM, Ehl S, Aichele P, et al. Antigen localization regulates immune responses in a dose- and time-dependent fashion: a geographical view of immune reactivity. Immunol Reviews 1997;156:199-209

118. Zinkernagel RM, Bachmann MF, Kundig TM, et al. On immunological memory. Ann Rev Immunol 1996;14:333-367

119. Doherty PC, Zinkernagel RM. A biological role for the major histocompatibility antigens. Lancet 1975;2:1406-1409

120. Zinkernagel RM, Doherty PC. The discovery of MHC restriction. Immunology Today 1997;18:14-17

121. Nemlander A, Soots A, von Willebrand E, Husberg B, Hayry P. Redistribution of renal allograft-responding leukocytes during rejection. II. Kinetics and specificity. J Exp Med 1982;156: $1087-1100$

122. Larsen CP, Morris PJ, Austyn JM. Migration of dendritic leukocytes from cardiac allografts into host spleens. A novel route for initiation of rejection. J Exp Med 1990;171:307-314

123. Demetris AJ, Qian S, Sun H, et al. Early events in liver allograft rejection: delineation of sites simultaneous intragraft and recipient lymphoid tissue sensitization. Am J Pathol 1991;138: 609-618

124. Zinkernagel RM, Hengartner H. Antiviral immunity. Immunology Today $1997 ; 18: 258-260$

125. Lenardo M, Chan FK, Hornung F, et al. Mature lymphocyte apoptosis-immune regulation in a dynamic and unpredictable antigen environment. Ann Rev Immunol 1999;17:221-253

126. Li Y, Li XC, Zheng XX, et al. Blocking both signal 1 and signal 2 of T-cell activation prevents apoptosis of alloreactive $T$ cells and induction of peripheral allograft tolerance. Nature Medicine 1999;5:1298-1302

127. Wells AD, Li XC, Li Y, et al. Requirement for T-cell apoptosis in the induction of peripheral transplantation tolerance. Nature Medicine 1999;5:1303-1307

128. Wood K, Sảchs DH. Chimerism and transplantation tolerance: cause and effect. Immunol Today 1996;17:584-587

129. Terakura M, Murase N, Demetris AJ, et al. Lymphoid/nonlymphoid compartmentalization of donor leukocyte chimerism in rat recipients of heart allografts, with or without adjunct bone marrow. Transplantation 1998;66:350-357

130. Ohashi PS, Oehen S, Buerki K, et al. Ablation of "tolerance" and induction of diabetes by viruses infection in viral antigen transgenic mice. Cell 1991;65:305-317

131. Ohashi PS, Oehen S, Aichele P, et al. Induction of diabetes is influenced by the infectious virus and local expression of MHC class I and tumor necrosis factor- $\alpha$. J Immunol 1993;150: 5185-5194

132. Ko S, Deiwick A, Jager MD, et al. The functional relevance of passenger leukocytes and microchimerism for heart allograft acceptance in the rat. Nature Medicine 1999;5:1292-1297

133. Ehl S, Aichele P, Ramseier $\mathrm{H}$, et al. Antigen persistence and time of T-cell tolerization determine the efficacy of tolerization protocols for prevention of skin graft rejection. Nat Med 1998;4: 1015-1019

134. Salgar S, Shapiro R, Dodson F, et al. Infusion of donor leukocytes to induce tolerance in organ allograft recipients. J Leukoc Biol 1999;66:310-314

135. Hart DNJ, Winearls CG. Fabre JW. Graft adaptation: studies on possible mechanisms in long-term surviving rat renal allografts. Transplantation 1980;30:73-80

136. Thai NL, Qian TS, Fu F, et al. Mouse liver transplantation tolerance: the role of hepatocytes and nonparenchymal cells. Transplant Proc 1995;27:509-510

137. Sriwatanawongsa V, Davies HS, Calne RY. The essential roles of parenchymal tissues and passenger leukocytes in the tolerance induced by liver grafting in rats. Nat Med 1995;1:428-432

138. Bumgardner GL, Li J, Heininger M, Orosz CG. Costimulation pathways in host immune responses to allogeneic hepatocytes. Transplantation 1998;66:1841-1845

139. Bumgardner GL, Heininger $\mathrm{M}, \mathrm{Li}$ J, et al. A functional model of hepatocyte transplantation for in vivo immunologic studies. Transplantation 1998;65:53-61

140. Bumgardner GL, Li J, Heininger M, Ferguson RM, Orosz CG. In vivo immunogenicity of purified allogeneic hepatocytes in a murine hepatocyte transplant model. Transplantation 1998;65: $47-52$ 